\title{
DuN-525. 24
}

Cover Sheet for a Hanford Historical Document

Released for Public Availability

Released 1994

Prepared for the U.S. Department of Energy under Contract DE-AC06-76RLO 1830

Pacific Northwest Laboratory Operated for the U.S. Department of Energy by Battelle Memorial Institute

*attelle

BEO

OEC 1310

OSTI 


\section{DISCLAIMER}

This report was prepared as an account of work sponsored by an agency of the United States Government. Neither the United States Government nor any agency thereof, nor any of their employees, make any warranty, express or implied, or assumes any legal liability or responsibility for the accuracy, completeness, or usefuiness of any information, apparatus, product, or process disclosed, or represents that its use would not infringe privately owned rights. Reference herein to any specific commercial product, process, or service by trade name, trademark, manufacturer, or otherwise does not necessarily constitute or imply its endorsement, recommendation, or favoring by the United States Government or any agency thereof. The views and opinions of authors expressed herein do not necessarily state or reflect those of the United States Government or any agency thereof. 


\section{DISCLAIMER}

Portions of this document may be illegible in electronic image products. Images are produced from the best available original document. 
DOCUMENT NO.

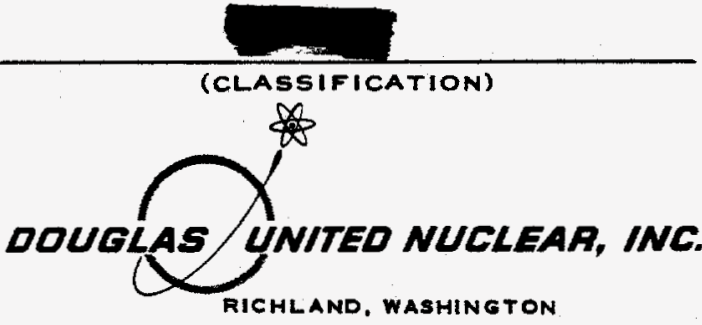

DUN-525 24

Hanfora Category 065

SERIES AND COPY NO.
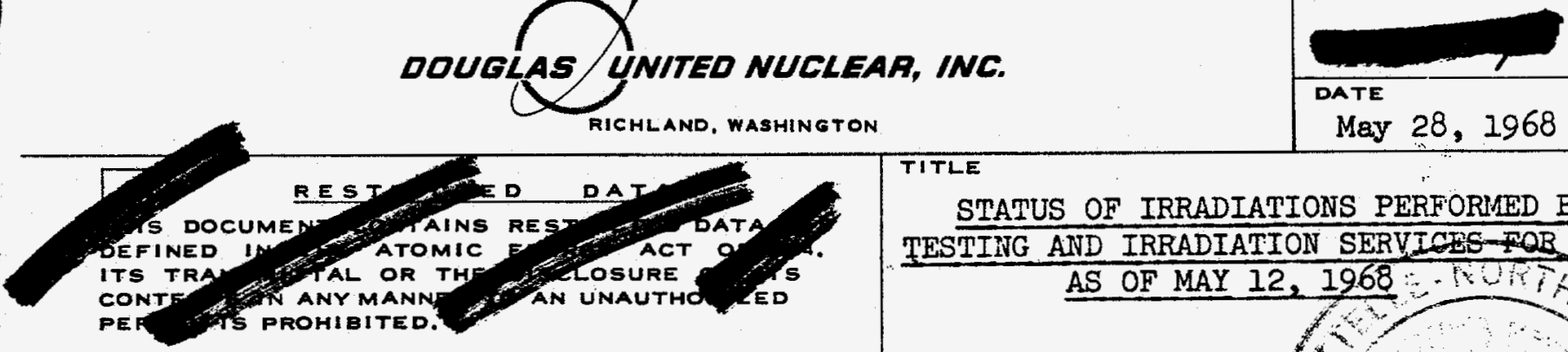

OTHER OFFICIAL CLASSIFIED INFORMATION

THIS MATERIAL CONTAINS INFORMATION AFFECTING

THE NATIONAL DEFENSE OF THE UNITED STATES

WITHIN THE MEANING OF THE ESPIONAGE LAWS,

TITLE 18, U.S.C., SECS. 793 AND 794, THE TRANS-

MISSION OR REVELATION OF WHICH IN ANY MANNER

TO AN UNAUTHORIZED PERSON IS PROHIBITED BY

TITLE

May 28, 1968

LAW.

STATUS OF IRRADIATIONS PERFORMED BY TESTING AND IRRADIATION SERVICES-FOB BNW

\section{AUTHOR}

L. V. Barker
Juk 7 1960.

CIRCULATING COPY

N/CAL INFO.

THIS DOCUM UST NOT BE LEFT WTENDED OR WHERE AMUNAUTHORIZED PERSO

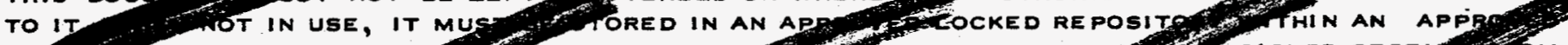

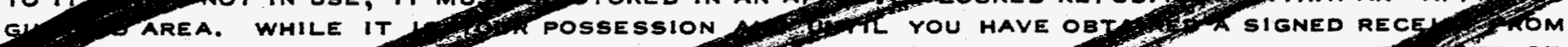

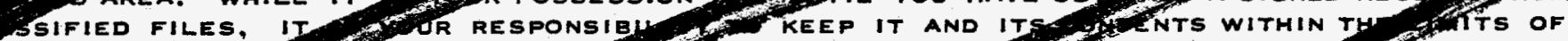

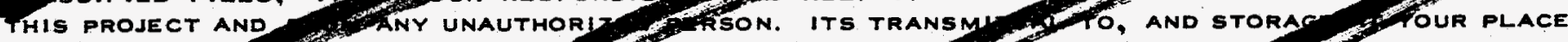

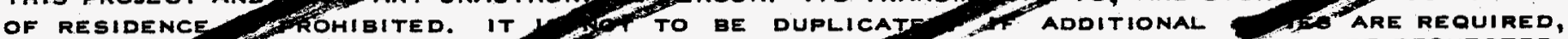
OBTAIN THF TIOM THE RELATEP OING FILE. ALL PEE READING THIS DOCUITENT ARE REQUESTED TO SIG RE SPACE PROVIDED LOW.

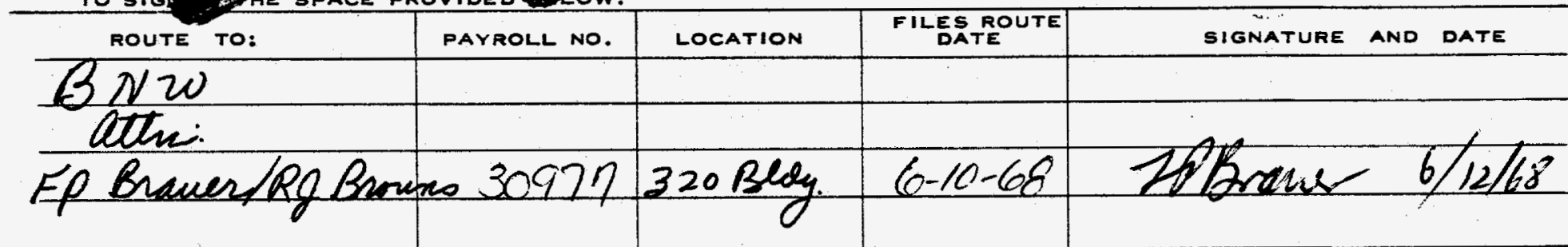


DUN-525 24

Hanford Category C-65

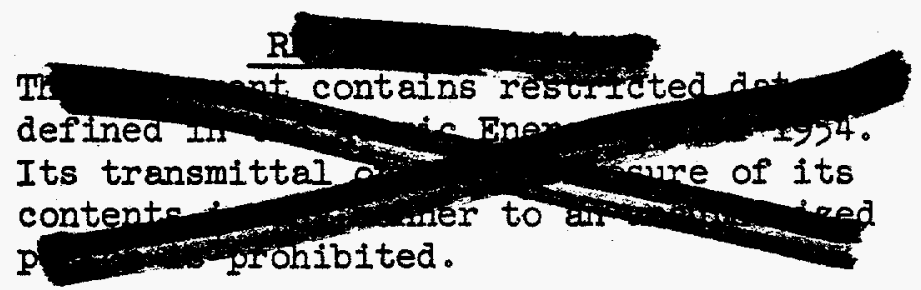

This document consists of

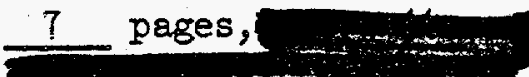

DISTRIBUTION

1. IV Barker

2. DUN File

3. DUN Record

Battelle-Northwest

4. FP Brauer/RJ Brouns

5. TI Claudson

6. As Jervis

7. RD Leggett

STATUS OF IRRADIATIONS PERFORMED BY TESTING AND IRRADIATION SERVICES FOR BNW AS OF MAY 12,1968

I. V. Barker
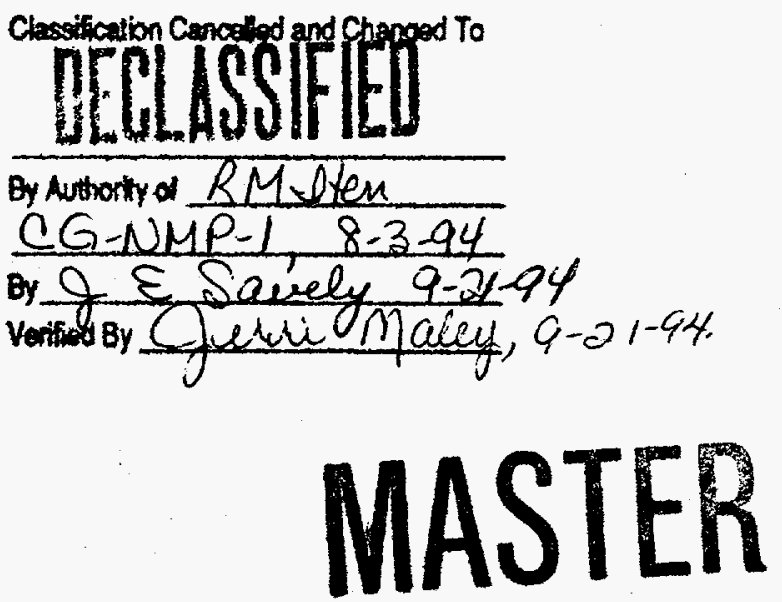
This report itemizes the irradiations performed by Testing and Irradiation Services for Battelle-Northwest. It lists the material being irradiated, awaiting disposition and material shipped during the report period. An explanation of the varlous columns in the report follows:

\section{Identification}

a. TISR No. - This is the official number assigned by Testing and Irradiation Services to an experiment for purposes of identification.

b. Request Number - Customer experiment identification number, if any.

c. Material - The principle target material, if known, abbreviated or its chemical symbol in capital letters.

d. Piece Number - Individual sample or assembly identification.

Operating Time (Days) - Tre number of full-power operating days the sample has been exposed.

CMK Absorbed - The total cmk absorbed by the sample. Does not include the facility.

Charge Date - Date and time sample charged into reactor or date and time reactor reached one-half equilibrium level if sample was charged during a reactor outage.

\section{Location}

a. Facility - Test facility or process tube and reactor containing the experiment.

b. Test Hole Position - Sample position in-reactor relative to a process tube.

c. Position Factor - Location of sample in relation to front-to-rear cosine flux distribution. (This factor only applies to front-to-rear irradiations.)

NOTE: The actual shape may deviate from a cosine curve due to local perturbations. The actual shape will be provided upon request.

Exposure to Date - NVT - The total thermal neutron exposure per square centimeter received to date. This number is calculated from facility unperturbed flux and reactor operating time.

Discharge, Date and Time - Date and time samples were removed from the active portion of the reactor or date and time reactor was down to one-half equilibrium level if sample was discharged during a reactor outage.

Shipping Date - Date samples were shipped to the customer or otherwise disposed of.

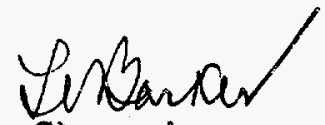

süpervisor

Irradiation Testing

LV Barker $/ \mathrm{k}$ 


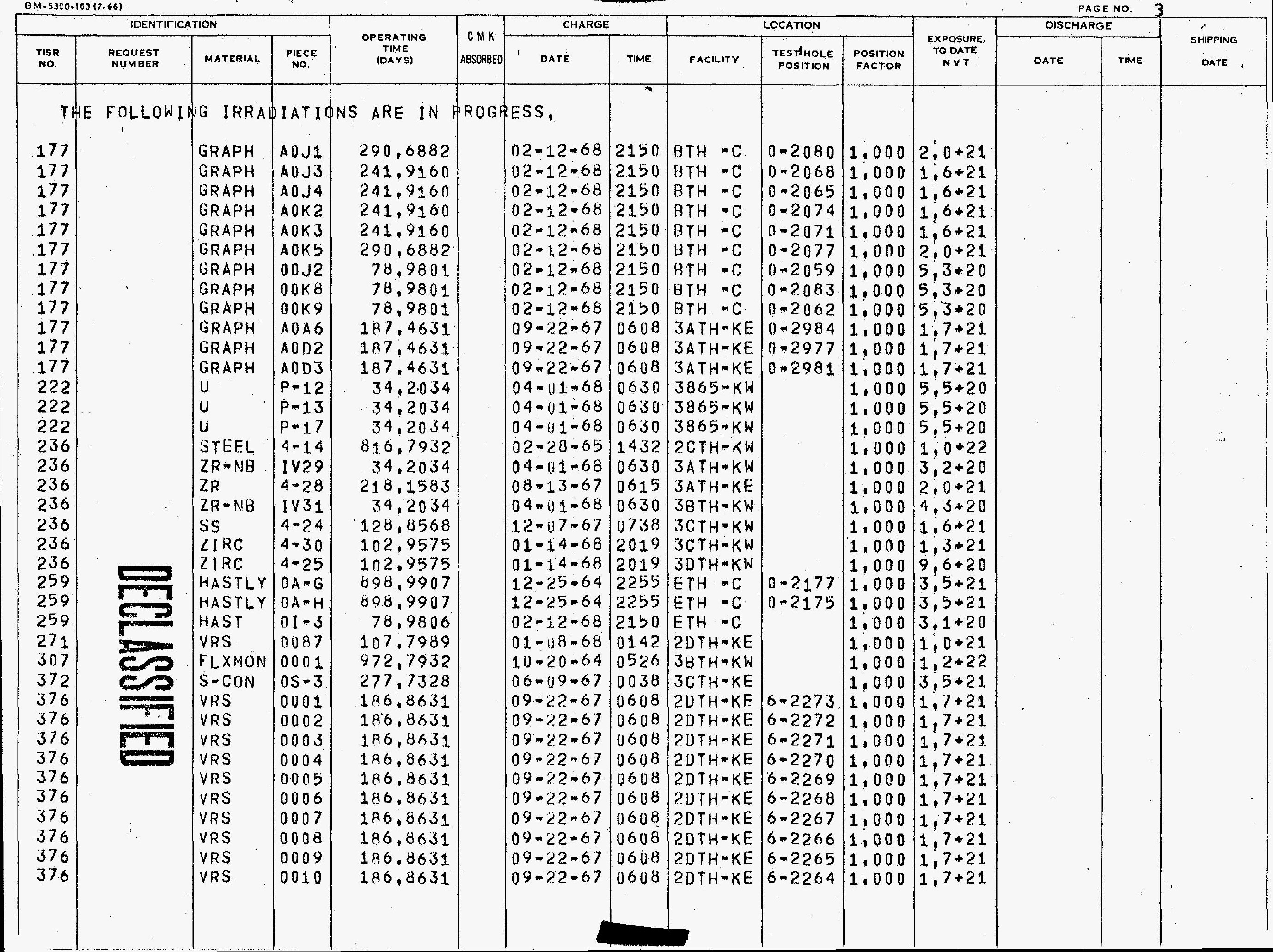




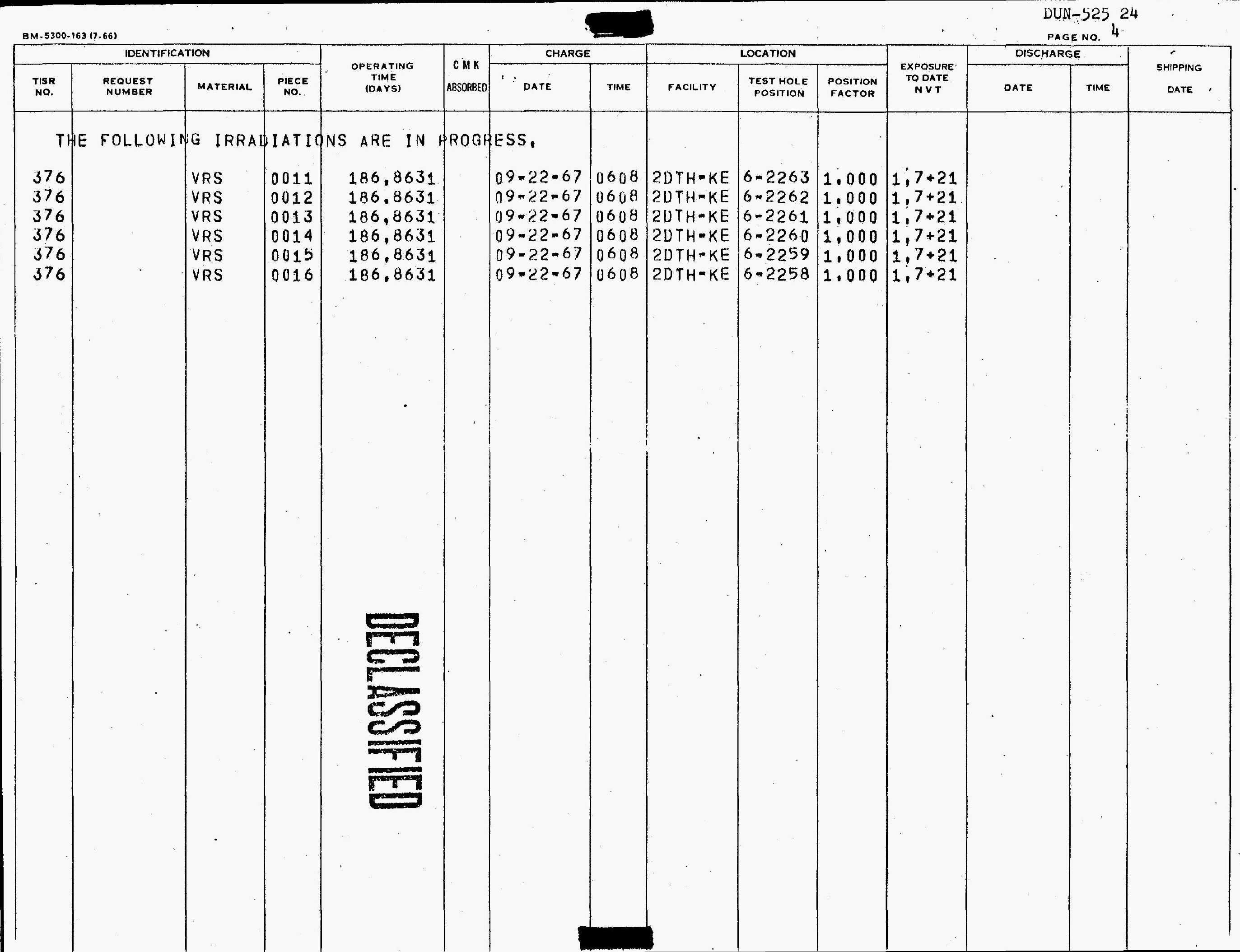




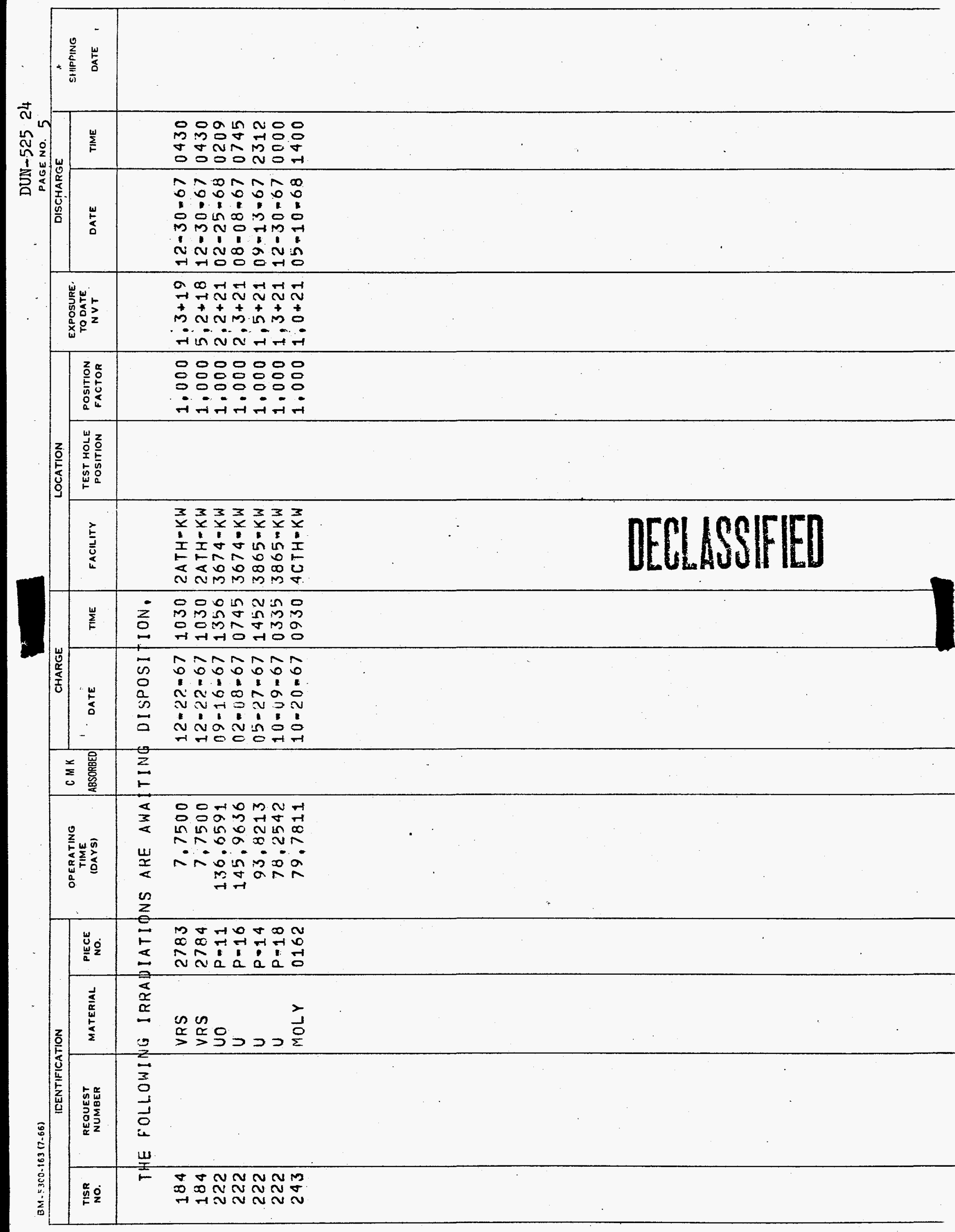




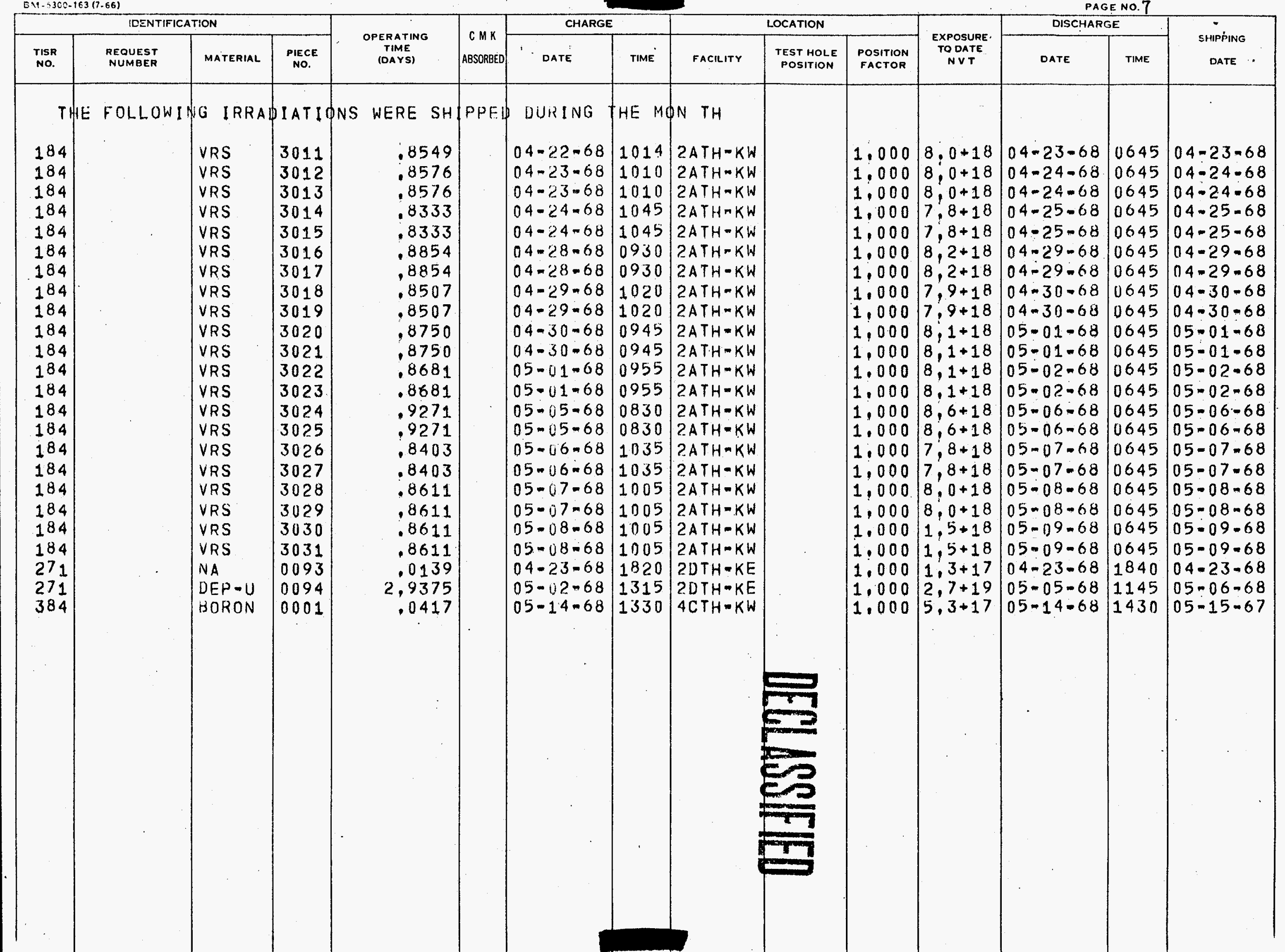

